\title{
Regulating Religion through Administrative Law
}

\author{
Religious Conversion in Malaysia beyond Fundamental Rights
}

\author{
Matthew Nelson" and Dian A. H. Shah
}

\section{INTRODUCTION}

As a basic human right, the notion of religious freedom - including the right to choose and change one's religion - is often associated with complex procedural requirements tied to specific forms of state recognition. This administrative link between religious identity and state recognition is particularly important where a change in religion affects one's relationship with related religious laws or institutions (e.g., privileged access to religious education or benefits). The balance between a fundamental right to religious self-identification and the administrative procedures surrounding state recognition raises challenging questions. When do administrative procedures amount to an excessive burden and, thus, a violation of one's fundamental rights? What role should states have when individuals decide to change their religious identification?

Cases of religious conversion are often complex. On the one hand, conversion is tied to religious profession as a fundamental right. On the other, conversion often involves forms of state recognition with all of the administrative requirements this entails: "formal" applications to change one's religion, notarized declarations, detailed paperwork, bureaucratic discretion, and so on. These hurdles move beyond the question of religious profession to include a range of questions about the manifestation of one's religious identity within the public realm.

Human rights advocates typically describe the right to profess a specific religion or belief (religious self-identification) as absolute. ${ }^{1}$ This is the forum internum aspect of one's right to religious freedom (a right to belief in the private realm) as opposed to the forum externum aspect - a right to manifest one's belief through public practice

Both authors thank the participants of the Regulating Religion Workshop held at the National University of Singapore Faculty of Law (December 16-17, 2015) for their comments.

1 Nurjaanah Abdullah, "Legislating Faith in Malaysia," Singapore Journal of Legal Studies (2007), 264, 274. See also Manfred Nowak, U.N. Covenant on Civil and Political Rights: CCPR Commentary (N. P. Engel, 1993). 
and expression. ${ }^{2}$ This distinction is evident in numerous international human rights instruments such as the International Covenant on Civil and Political Rights (ICCPR) and the Universal Declaration of Human Rights (UDHR), both of which provide that matters of public manifestation may be subject to constraints established by law. The disagreement, however, relates to what a proper limit to religious manifestation might be. With respect to the forum internum aspect, scholars such as Manfred Nowak have argued that the private practice of one's religion (whether individually or with others) cannot be restricted. ${ }^{3}$ But even this has not been completely straightforward - even in jurisdictions that guarantee a constitutional right to religious freedom. Constraints are frequently imposed on one's individual right to choose one's religion, including administrative requirements that constitute a regulatory barrier to the state's recognition of one's (ostensibly private) choice. We focus on this latter aspect of state regulation - the introduction of administrative procedures that underpin a state's recognition of religious identity.

Administrative procedures are ubiquitous in cases of religious recognition. But what counts as a "reasonable" administrative burden? In this chapter, we argue that administrative and procedural burdens figure as an inevitable feature of state recognition. However, we also argue that, within this realm, questions regarding the "reasonableness" of procedures - in effect, questions that lie at the heart of any effort to understand the operationalization of religious freedom - are historically and politically contingent. The operationalization of a fundamental right to religious freedom, in other words, differs from place to place owing to different standards framing the parameters of "reasonable" administrative procedures.

To demonstrate our arguments, we examine the famous religious-conversion case of Lina Joy in Malaysia. ${ }^{4}$ In this case, historically and politically contingent notions of administrative "reasonableness" emerged as a crucial variable in the state-based operationalization of religious liberty. But our argument is not confined to Malaysia. It extends to Jews in London, Christians in the United States, and many other contexts. ${ }^{5}$ In all of these cases, the question is similar: when do the administrative procedures associated with a state's recognition of religious identity amount to an "unreasonable" infringement on that identity and, thus, a violation of fundamental rights? Is there any universal standard to answer such questions?

It is important to stress that registration requirements pertaining to religious identity are not uncommon. Aside from the Malaysian, American, and British cases we discuss, focusing on individual religious identity, a study of 153 states with

2 See M. Todd Parker, "The Freedom to Manifest Religious Belief: An Analysis of the Necessity Clauses of the ICCPR and the ECHR," Duke Journal of Comparative and International Law 17.1 (2006), 91 and Anat Scolnicov, The Right to Religious Freedom in International Law: Between Group Rights and Individual Rights (Routledge, 2011).

3 Parker, ibid. (quoting Nowak [n. 1], 319).

4 Lina Joy v. Majlis Agama Islam Wilayah G Anor [2007] 4, Malayan Law Journal 585.

5 See, e.g., Burwell v. Hobby Lobby Stores, Inc. [2014] 573 U.S.; R v. The Governing Body of JFS [2009] UKSC 15 . 
constitutional guarantees pertaining to freedom of worship revealed that 42 percent impose some form of registration requirement with reference to religious groups. ${ }^{6}$ Indeed, among those that constitutionalize a "separation" of religion and state, fully 86 percent enforce laws concerning religious registration. ${ }^{7}$

In Lina Joy, claims of administrative "unreasonableness" pertaining to religious self-identification were related to the state's insistence that, before it could recognize the identity of a Muslim-to-Christian convert named Lina Joy, Joy would have to complete a series of procedures that did not yet exist. This administrative burden struck many as unreasonable. Yet, for richly contextualized reasons deeply rooted in Malaysia's constitutional and legal history (specifically concerning the bodies that might be charged with defining the relevant policies and administrative procedures underpinning the possibility of state recognition), this procedural burden was judged to be "reasonable." 8 Briefly, Malaysia's Federal Court insisted that specific procedures grounded in deeply contextualized notions of administrative "reasonableness" need not imply a total denial of constitutionally protected religious liberty. In fact, the chief justice who delivered the Federal Court's majority decision did not categorically reject the possibility of a Muslim's renunciation of Islam; he merely suggested that any person seeking to leave the religion must follow the relevant procedures for doing so. ${ }^{9}$ In short, the chief justice noted that religious freedom was protected so long as each actor - bureaucratic officials, elected representatives, and private citizens - followed the rules set out in Malaysia to create (and adhere to) relevant procedures. In Joy's case, the chief justice merely suggested that, once Joy had fulfilled the procedures to renounce Islam and the relevant Islamic authorities had "authorized" her apostasy, she could embrace the religion of her choice. ${ }^{10}$

To locate the importance of historically contingent notions of administrative "reasonableness" within the literature regarding religious freedom and human rights, this chapter offers a close reading of one case - the case of Lina Joy - in three parts. Part I describes the legal, political, and administrative landscape of Malaysia as this relates to issues of religious conversion away from Islam, drawing special attention to Malaysia's federal structure and its dual court system involving (a) a hierarchy of civil courts (stretching up to the Malaysian Federal Court) as well as (b) a hierarchy of state-level shari'ah courts overseen by state-level sultans who function as the constitutional Heads of Islam in their respective states. Beyond this dual court system, some attention is also paid to the constitutional limits faced by Malaysia's state-level shari'ah courts (in terms of their punitive jurisdiction) and,

6 Jonathan Fox and Deborah Flores, "Religions, Constitutions, and the State: A Cross-National Study," Journal of Politics 41.4 (2009), 1499, 1509.

7 Ibid., 1510.

$8 \quad \operatorname{Lina} \operatorname{Joy}($ n. 4), 607-8.

9 Ibid., 618.

$10 \quad$ Ibid., 612. 
since 1988, the jurisdictional limits faced by Malaysia's civil courts vis-à-vis their review of judgments pertaining to shari'ah.

Politically, the role of state-level statutory enactments seeking to highlight the terms of Islamic law in matters of Muslim apostasy will also be discussed, along with the role of Malaysia's Department of Islamic Development, or JAKIM (Jabatan Kemajuan Islam Malaysia), within the Malaysian Prime Minister's Office. With support from JAKIM, several Malaysian states have adopted broadly similar administrative procedures pertaining to Muslim personal law, including marriage, divorce, and conversion to Islam. This push in the direction of national standards, however, has not affected conversions away from Islam. In fact, different Malaysian states continue to address the issue of Muslim apostasy in different ways, with some including the Federal Territories in which the case of Lina Joy emerged - failing to address it at all. As a constitutional, political, and administrative matter, this is the policy-based procedural lacuna that shaped the fundamental rights of Lina Joy.

Part II provides a detailed reading of Lina Joy, highlighting the ways in which Joy's lawyers and the Federal Court opted to set aside the language of fundamental rights in favor of a specific focus on the administrative procedures whereby Joy's religious identity was to be officially recognized. Particular attention will be paid to the policy-based lacuna mentioned earlier and, within this, the legal view that expecting Joy to complete a set of as-yet-non-existent forms could be seen as administratively "reasonable."

Part III examines the literature regarding this lacuna in more detail. Joy herself suggested that, when officials based in Malaysia's National Registration Department (NRD) refused to delete the word "Islam" from her national ID card (a step that was, in many ways, directly shaped by the procedural lacuna we investigate), they were performing a "trick" designed to prevent the state from recognizing her conversion away from Islam. ${ }^{11}$ Others, however, tied the presence of this lacuna to specific religious and political factors, including an intrinsic aversion within the Islamic law overseen by Malaysia's state-level shari'ah courts to any recognition for the act of Muslim apostasy itself. ${ }^{12}$

After considering these alternative explanations, we offer another account of the policy-based lacuna that undermined the state's recognition of Lina Joy's conversion, focusing on the relationship between Malaysian legal and political realities (including powerful ideas about the parameters of a "reasonable" administrative procedure for Muslim apostasy within Malaysia's constitutional order). In effect, we draw attention to an historically embedded set of legal and political disagreements regarding the promulgation of relevant administrative standards, noting that these disagreements must be read as a crucial empirical variable connecting a fundamental right to religious self-identification with the possibility (or the mode) of state

11 Ibid., 62o.

12 See Tamir Moustafa, "The Politics of Religious Freedom in Malaysia," Maryland Journal of International Law 29.1 (2014), 481. 
recognition in Malaysia. We do not set aside the issue of fundamental rights already examined at length in the literature regarding Lina Joy. Instead, we argue that a deep understanding of local disagreements regarding administrative procedures in Malaysia is essential for those with an interest in grasping the operationalization of fundamental rights as they actually unfold on the ground.

Focusing on the operationalization of fundamental rights in a highly politicized context shaped by religious norms, we argue that the operationalization of fundamental rights is politically contingent insofar as it is channeled through official procedures framed by deeply contextualized notions of administrative "reasonableness." Our argument regarding the operationalization of fundamental rights is, thus, an argument focusing on the primacy of politics. Briefly stated: political considerations underpin the formal legal assessments of administrative "reasonableness" that, in turn, shape the operationalization of each state's recognition of a fundamental right to religious self-identification.

\section{CONTEXTUALIZING MUSLIM CONVERSION IN MALAYSIA}

To understand the legal context within which Lina Joy's effort to obtain state recognition for her religious conversion unfolded, it is necessary to grasp certain features of Malaysia’s Federal Constitution. The British colony of Malaya achieved its independence in 1957 from a set of territories known as the Straits Settlements as well as the Federated and Unfederated Malay States. The Straits Settlements (Malacca, Penang, Singapore, etc.) were directly administered by the British Crown, and in those settlements the terms of Muslim personal law were closely tied to Anglo-Mohammadan law as it had developed in British India. In the Federated and Unfederated Malay states, however, British representatives worked with regional sultans, who retained de jure sovereignty with respect to both Muslim and customary law. ${ }^{13}$

During Malaya's anticolonial nationalist movement, many regional sultans were allied with the United Malays Nationalist Organisation (UMNO), and, after independence, the country arrived at a constitutional settlement that provided for a dual court system separating the country's centralized "civil" courts from its regional (state-level) "Muslim" courts. ${ }^{14}$ Malaya was renamed Malaysia in 1963 , and in 1976 the country's Muslim courts (overseen by hereditary sultans) were renamed as statelevel "shari“ah" courts.

The de jure sovereignty of Malaysia's regional sultans with respect to Islamic law and these state-level shari'ah courts was preserved in Malaysia's Federal Constitution. Article 11(5) protects religious freedom (“subject to public order")

13 Andrew Harding, Law, Government, and the Constitution in Malaysia (Kluwer Law International, 1993), 13 .

14 See generally Hari Singh, "UMNO Leaders and Malay Rulers: The Erosion of a Special Relationship," Pacific Affairs 68 (1995), 187. 
even as Article 3 stipulates that "Islam is the religion of the Federation". Initially, many of Malaya's regional sultans objected to Article 3, believing it would encroach on their religious authority within their respective states. ${ }^{15}$ However, when it was explained that Article 3 was symbolic - indeed, that the state-level religious authority of regional sultans would remain firmly intact - they accepted it. ${ }^{16}$ Separate constitutional articles define the ethnic category "Malay" as composed of persons who profess Islam ${ }^{17}$ while, at the same time, providing that certain "Islamic" matters will be governed by state-level shari'ah courts overseen by the country's regional or statelevel sultans. ${ }^{18}$ Together, these articles mean that matters concerning Islam and the personal law of those professing Islam are inextricably tied to the terms of Malaysian federalism and, thus, a delicate balance between Malaysia's central government, its regional sultans, and each state-level legislature.

The jurisdiction of Malaysia's state-level shari'ah courts is limited to matters allocated to them by state-level legislative action. ${ }^{19}$ This action, whether in the form of a legislative enactment or a fatwa issued by a state-level Mufti, is subject to approval by the relevant sultan before it can be gazetted and transformed into an enforceable law. In Malaysia's Federal Territories (e.g., in the Malaysian capital of Kuala Lumpur), the pattern is similar to that found in regions such as Washington, DC. Local institutions - including state-level shari'ah courts - exist, but it is the federal government that oversees them. In fact it is not a state-level sultan but Malaysia’s Yang di-Pertuan Agong (a national "king" elected on a rotating basis from among Malaysia's regional sultans) who oversees the state-level shari'ah courts in Federal Territories such as Kuala Lumpur. ${ }^{20}$ This is important because the case of Lina Joy originated in Kuala Lumpur.

\section{A. Muslim Conversion: Legal Debates}

The issue of conversion away from Islam - pertaining both to constitutional issues such as religious freedom ${ }^{21}$ and to state-level shari'ah enactments ${ }^{22}$ - was initially

15 Dian A. H. Shah, Constitutionalizing Religion and Religious Freedom: A Comparative Study of Malaysia, Indonesia, and Sri Lanka. SJD dissertation, Duke University, 2014, 266 (on file with Duke University Library).

16 Joseph M. Fernando, The Making of the Malayan Constitution (Malaysia Branch of the Royal Asiatic Society, 2006), 171.

17 Federal Constitution of Malaysia, Article 160(2).

18 Ibid., Article 74. This provision clarifies the legislative powers of Malaysia's federal and state-level governments with reference to the "federal," "state," and "concurrent" legislative lists set out in the constitution's Ninth Schedule.

19 Ibid., Ninth Schedule, List II.

20 For a discussion of the legal, political, and administrative structures surrounding Islamic law in Malaysia, see Farid S. Shuaib, "The Islamic Legal System in Malaysia," Pacific Rim Law E Policy Journal 21.1 (2012), 85 and Farid S. Shuaib, "Strengthening Administrative Institutions of Islamic Law in Malaysia: An Overview," Jumal Syariah 16 (2008), 443.

${ }^{21}$ Federal Constitution of Malaysia, Article 11.

22 Ibid., Ninth Schedule. 
perched in between Malaysia’s civil and shari'ah courts, with the civil courts maintaining powers of judicial review. However, since 1988, a constitutional amendment $^{23}$ carving out an exclusive sphere of jurisdictional authority for the shari'ah courts - primarily in matters of personal law - has been interpreted to prevent this form of judicial review. ${ }^{24}$ The amendment, Article $121(1 \mathrm{~A})$, was born out of a concern that the two courts were - as evidenced by several cases - issuing conflicting decisions. ${ }^{25}$ As a solution, Article $121(1 \mathrm{~A})$ was introduced to provide that shari'ah matters specified under List II (Paragraph One) of the constitution's Ninth Schedule (i.e., the state-level legislative list) must be handled exclusively by state-level religious courts. $^{26}$ It is an important amendment because, in conjunction with existing constitutional and federal statutory limits on the punitive powers of state-level courts - up to three years imprisonment, fines of MYR5000, and six lashes - it means that, although cases of Muslim apostasy are handled by state-level shari'ah courts, efforts to impose capital punishment (regarded, by some, as a suitable punishment for Muslim apostasy) are prohibited. ${ }^{27}$ Before Lina Joy, Malaysia's Supreme Court (as Malaysia's highest court was then called) declared that each state legislature was required to define an administrative procedure for its shari'ah courts to govern the

23 Ibid., Article 121(1A).

24 See, e.g., Shamrahayu A. Aziz, "Apostasy and Religious Freedom: A Response to Thio Li-Ann," Malayan Law Journal 2 (2007), i, v. Cf. Thio Li-Ann, "Apostasy and Religious Freedom: Constitutional Issues Arising from the Lina Joy Litigation," Malayan Law Journal 2 (2006), i, xivxvi. Thio argues that it is unclear whether the amendment effectively precludes the civil courts from adjudicating apostasy cases and that the view that shari'ah courts possess exclusive jurisdiction over apostasy cases is still contested.

25 Ahmad Ibrahim, "The Amendment of Article 121 of the Federal Constitution: Its Effect on the Administration of Islamic Law," Malayan Law Journal 2 (1989), xvii.

26 The provision states: "Except with respect to the Federal Territories of Kuala Lumpur and Labuan, [the state-level list includes] Islamic law and personal and family law of persons professing the religion of Islam, including the Islamic law relating to succession, testate and intestate, betrothal, marriage, divorce, dower, maintenance, adoption, legitimacy, guardianship, gifts, partitions and non-charitable trusts; ... [the] creation and punishment of offences by persons professing the religion of Islam against precepts of that religion, except in regard to matters included in the Federal List; the constitution, organisation and procedure of Syariah courts, which shall have jurisdiction only over person professing the religion of Islam and in respect only of any of the matters included in this paragraph, but shall not have jurisdiction in respect of offences except in so far as conferred by federal law, the control of propagating doctrines and beliefs among persons professing the religion of Islam; the determination of matters of Islamic law and doctrine and Malay custom."

27 Within Islamic law, the punishment for apostasy is debated. This issue is not addressed in the Qu'ran; it emerges in various hadith (sayings of the Prophet Mohammad) and, historically, different "schools" of Muslim jurisprudence have stressed different punishments. See generally, Frank Griffel, "Toleration and al-Shāfi'i and al-Ghazālì on the treatment of apostates," Bulletin of SOAS 64.3 (2001), 339, and Yohannan Friedmann, Tolerance and Coercion in Islam: Interfaith Relations in the Muslim Tradition (Cambridge University Press, 2003), 121-59. In 1990 Kelantan's Chief Minister (PAS) pressed for the imposition of capital punishment. UMNO suggested a constitutional amendment to enhance the jurisdiction of state-level courts (thereby avoiding accusations of standing in the way of shari'ah); but this idea was later withdrawn. See Andrew Harding, "The Keris, the Crescent and the Blind Goddess: The State, Islam and the Constitution in Malaysia," Singapore Journal of International \& Comparative Law 6 (2002), 154, 176-7. 
process of Muslim apostasy - up to and including discretionary efforts to deter apostasy within existing state-level punitive limits. ${ }^{28}$ The Court held that, if states failed to specify any procedure, this did not actually prohibit Muslim apostasy. Instead, the Court simply noted that recalcitrant states (or, in the case of Malaysia's Federal Territories, parliament itself) would have to frame statutory rules for their sultans (or the king) to endorse. This ruling stemmed from the fact that, according to the constitution's Ninth Schedule, explicit legislation was required to endow state-level shari'ah courts with jurisdiction over issues mentioned on the state-level legislative list. And, even then, state legislatures did not have the authority to enact just any law pertaining to Islam; they were limited to the promulgation of laws on a schedule of "Islamic" matters spelled out in Paragraph One of List II. ${ }^{29}$ Without specific enabling legislation, in other words, the 1988 constitutional amendment articulated in Article $121(1 \mathrm{~A})$ was not sufficient - on its own - to guide or empower Malaysia's state-level shari'ah courts.

Since 1988, however, several court cases have sought to clarify the relationship between Malaysia's federal constitution, including its state-level shari'ah courts, and the question of fundamental rights (with particular reference to the procedures underpinning Muslim apostasy). These cases framed the legal environment within which Lina Joy emerged. In 1991, the High Court was asked to decide whether a person from Selangor who had allegedly converted to Islam had died as a Muslim. ${ }^{30}$ The Court concluded that, because neither the Selangor Administration of Muslim Law Enactment (1952) nor the Islamic Family Law (Federal Territories) Act (1984) specifically mentioned the issue of conversion - in other words, because jurisdiction over this issue had not been transferred to Selangor's state-level shari'ah court by way of explicit legislative action - the matter should be heard by a (civil) High Court instead. ${ }^{31}$ But, in 1992, this view was modified in a case known as Dalip Kaur ${ }^{32}$ concerning the status of a man from Kedah who was said to have converted away from Islam before he passed away. In this case, the Supreme Court declared that the civil courts could not assume jurisdiction, because matters of Muslim apostasy required expert assessment by a qualified religious authority. ${ }^{33}$ Because the Kedah Administration of Muslim Law Enactment (1952) did not clarify the procedural mechanism whereby Muslims might leave Islam (indeed, because there was no explicit legislation clarifying the jurisdiction of Kedah's shari'ah courts in cases of

See generally Dalip Kaurv. Pegawai Polis Daerah, Balai Polis Daerah, Bukit Mertajam E Another [1992] 1, Malayan Law Journal 1.

29 Shad Saleem Faruqi, Document of Destiny: The Constitution of the Federation of Malaysia (The Star Publications, 2008), 134.

30 Ng Wan Chan v. Majlis Ugama Islam Wilayah Persekutuan \& Another (No. 2) [1991] 1, Malayan Law Journal 487 .

$31 \quad$ Ibid., 490.

32 Dalip Kaur (n. 28).

33 Ibid., 9 (concurring opinion by Justice Mohamed Yusoff). 
Muslim apostasy at all), however, the Court found that Kedah's civil courts were still empowered, by default, to render a binding decision. ${ }^{34}$

In 1998, however, the High Court adopted an entirely different approach, holding in the case of Md Hakim Lee ${ }^{35}$ that, even where explicit state-level legislation conferring jurisdiction on state-level shariah courts in matters of Muslim apostasy was not in place, there was no justification for granting "default" jurisdiction to the civil courts. ${ }^{36}$ On the contrary, according to Idrus Bin Harun (a parliamentary draftsman in the office of the Malaysian Attorney General), Md Hakim Lee held that jurisdiction in matters of Muslim apostasy lay with the shari'ah court given its jurisdiction over Muslim religious affairs, "even if no express provisions were provided in [a state-level statute]." 37 Muslim apostasy was left to state-level shari'ah courts, in other words, on the expectation that legislative guidance regarding appropriate procedures would be forthcoming: "The fact that the plaintiff might not [yet] have his remedy in the syariah courts," noted Harun, "would not make the jurisdiction exercisable by [a civil] High Court." ${ }^{8}$

The view in Md Hakim Lee was later reinforced in a landmark case known as Soon Singh, ${ }^{39}$ where it was found that although each state (including the Federal Territories) had explicit laws covering conversion to Islam, only some had provided their shariah courts with explicit jurisdiction over conversions away from Islam. ${ }^{40}$ In Soon Singh, however, the Federal Court concluded that, in cases of Muslim apostasy, the jurisdiction of state-level shari'ah courts could be implied given the special religious expertise required to judge such cases. ${ }^{41}$ This approach was taken to a different level in a subsequent case known as Shaik Zolkaffily, ${ }^{42}$ wherein the Federal Court held that where jurisdiction over a specific issue had been conferred to the shariah courts - either explicitly or implicitly - but no legal remedy had been specified (by statute) within those courts, it was still the state legislature that was expected to determine the legal remedy within the shari'ah courts. ${ }^{43}$ In other words, "the fact that [a litigant] did not [yet] have his remedy in the syariah court would not make the jurisdiction exercisable by the civil court." 44 This is the jurisprudential background that set the stage for Lina Joy.

34 Ibid., 7 .

35 Md Hakim Lee v. Majlis Agama Islam Wilayah Persekutuan, Kuala Lumpur[1998] 1, Malayan Law Journal 681.

36 Ibid., 689.

37 Dato Idrus bin Harun, "Interaction between Syariah Law and Civil Law," Inaugural Annual Events (IAE) of the AGCs, Singapore, March 23-25, 2006.

$3^{8}$ Ibid.

39 Soon Singh v. Pertubuhan Kebajikan Islam Malaysia (PERKIM) Kedah [1999] 1, Malayan Law Journal 489 .

$4 \circ$ Ibid., 501.

41 Ibid., 502 .

$4^{2}$ Majlis Ugama Islam Pulau Pinang dan Seberang Perai v. Shaik Zolkaffily bin Shaik Natar E Others [2003] 3, Malayan Law Journal 705.

43 Ibid., 719.

44 Ibid. 
During the 1980s and 1990s, several states passed laws specifying a procedure concerning Muslim apostasy to be overseen by their state-level shariah courts. In Pahang, Perak, Malacca, and Sabah, these enactments identified Muslim apostasy as an offense - for example, an "offense by persons professing ... Islam against the precepts of that religion" (Constitution of Malaysia, Ninth Schedule, List II, Paragraph One) - to be punished with fines and/or imprisonment. ${ }^{45}$ But, in Negeri Sembilan, steps were put in place allowing state-level shariah courts to oversee the process of Muslim apostasy (including three months of counseling and a further oneyear cooling-off period) before an official certification of Muslim apostasy could be issued. ${ }^{46}$ And, in Johor, the unreported case of Ismail bin Suppiah ${ }^{47}$ decided by the Kuala Lumpur High Court noted that, as per the (now-repealed) Johor Administration of Islamic Law Enactment (1978), the chief kadi was simply expected to play a mechanical role in registering the non-Muslim name of any Johor-based Muslim who declared himself an apostate..$^{8}$ In the Administration of Islamic Law (Federal Territories) Act (1993) and at least four other states, however, the issue of Muslim apostasy was not addressed. The question underpinning the case of Lina Joy was therefore as follows: why did this statutory (and, thus, procedural) lacuna persist in Malaysia's Federal Territories even after the Federal Court clearly urged it to be filled? This is the procedural question that underpinned specific concerns about the administrative operationalization of religious freedom in Malaysia.

\section{B. Muslim Conversion: Political Debates}

Apart from this jurisprudential and legislative context, it is important to appreciate the larger political context within which Malaysian cases of Muslim apostasy were addressed. Throughout the latter half of the twentieth century, much depended on a pattern of electoral competition between two leading political parties: the right-ofcenter United Malays National Organization (UMNO) - the dominant collaborator in a ruling coalition known as the Barisan Nasional (BN) or National Front - and the religiously conservative (Islamist) Parti Islam Se-Malaysia (PAS). Since its inception in the early 1950s, PAS projected itself as the only truly "Islamic" party in Malaysia, vowing to form an Islamic state in which only Muslims would hold political power. ${ }^{49}$ In fact, for much of the country's history, and especially since the late 1970 s when social and political movements took on a more overtly religious

45 See, e.g., Crimes (Syariah) Enactment 1992 (Enactment No. 3 of 1992), Sections 12 and 13, and the Administration of the Religion of Islam and the Malay Custom of Pahang Enactment 1982, Sections 103 and 185 .

46 Administration of the Religion of Islam (Negeri Sembilan) Enactment 2003, Section 119.

47 Ismail bin Suppiah v. Ketua Pengarah Pendaftaran Negara (R-1-24-31-95) (unreported case).

$4^{8}$ See the Johor Faith Protection Bill 2000, which resembled a bill passed that year in Perlis.

49 Andrew Harding, "Sharia and National Law in Malaysia," in Jan Michiel Otto (ed.), Sharia Incorporated: A Comparative Overview of the Legal Systems of Twelve Muslim Countries in Past and Present (University of Chicago Press, 2010), 502-3. 
character, UMNO and PAS competed for Malay-Muslim votes - especially in the north and east of the country (a.k.a. Malaysia's Malay-Muslim "heartland"). ${ }^{\circ}$

Central to this ongoing electoral competition has been a push to construct a cohesive Malay-Muslim constituency by "defending" the boundaries of Islam or, at least, appearing to defend Muslim interests. UMNO and PAS, in other words, have frequently sought to "out-Islamize" one another by highlighting issues that touch on Malay-Muslim religious and political sensitivities. ${ }^{51}$ This competitive posture stretches all the way from policing various forms of religious orthodoxy to discouraging Muslim apostasy. The government's emphasis on Islam, for instance, was officially expressed during UMNO's 1982 General Assembly, when Prime Minister Mahathir Mohamad stressed that UMNO would ensure Malay-Muslim adherence to various Islamic teachings. ${ }^{52}$ In fact, certain reform initiatives took place even before Mahathir assumed office. At the federal level, for instance, the government established a National Council for Islamic Affairs (Pusat Islam) under the Department of Religion, which was later reorganized in the office of Prime Minister Mahathir as Malaysia's Department of Islamic Development (JAKIM). ${ }^{53}$ Within Malaysia, each state maintains its own Islamic affairs department. However, JAKIM has become increasingly influential over time in coordinating interstate Muslim affairs (particularly insofar as states have become more and more reliant on funds derived from the center). ${ }^{54}$ Today, JAKIM's wide-ranging role extends from the vetting of Friday sermons across Malaysia to the issuance of national procedures for determining the end of Ramadan. In the past, the end of Ramadan was determined by states using visual sightings of the moon and/or astronomical calculations. ${ }^{55}$ But, when Prime Minister Mahathir stepped in to centralize this moonsighting process, he reinforced deep-seated federal-state tensions as well as the terms of an enduring rivalry between Malaysia's national executive and its various regional sultans. ${ }^{56}$

JAKIM also recommends draft laws for state-level enactment. ${ }^{57}$ In fact, given its persistent political dominance across Malaysia during the 1980s and 1990s (except in

50 Shah (n. 15), 344 .

$51 \quad$ Ibid., 386.

52 Gordon P. Means, Political Islam in Southeast Asia (Lynne Rienner, 2009), 126.

53 Ibid.

54 See Maznah Mohamad, "The Ascendance of Bureaucratic Islam and the Secularization of the Sharia in Malaysia," Pacific Affairs 83.3 (2010), 505.

55 Means (n. 52), 128.

56 Means suggests that Mahathir overstepped the boundaries of his executive authority because Malay rulers possess "constitutionally defined powers ... over matters related to Islam." Means (n. 52), 128. However, Shad Faruqi notes that not everything concerning Islam is reserved to the states. Shad Saleem Faruqi, "Jurisdiction of State Authorities to Punish Offences against the Precepts of Islam: A Constitutional Perspective," The Malaysian Bar (September 24, 2005), www.malaysianbar.org.my/ constitutional_law/jurisdiction_of_state_authorities_to_punish_offences_against_the_precepts_of_i slam_a_constitutional_perspective.html (accessed September 2, 2015).

57 Means (n. 52), 126. 
Kelantan, where PAS won state-level elections in 1990), the ruling BN found it relatively easy to standardize state-level laws concerning various aspects of Islam. Indeed, even within Malaysia's federalized approach to Islam, the link between federal and state-level party politics has generally ensured that shariah-based policies governing marriage, the administration of Islam, and certain civil and criminal procedures (albeit not Muslim apostasy) were gradually harmonized over time. But, with reference to the focus of this article (Muslim apostasy), the question is: why did this steady march of standardization fail? Moreover, turning to Lina Joy, why was the procedural lacuna left by this failure seen as legally (and administratively) "reasonable"?

\section{UNDERSTANDING LINA JOY: FROM FUNDAMENTAL RIGHTS TO ADMINISTRATIVE LAW}

By the time Lina Joy reached Malaysia's Court of Appeal and, then, Malaysia's Federal Court, Joy's quest to obtain state recognition for her religious conversion by deleting the word "Islam" from her national ID card - was explicitly framed as a case of administrative law rather than fundamental rights. The facts were simple. Initially, Azalina binti Jailani (a.k.a. "Lina Joy") applied to change the name on her ID card (which did not mention her religion), stating that the reason for this change was a "change of religion" from Islam to Christianity. Her application, however, was denied, and Joy was advised to apply again, stating that the reason for her change of name was her "choice" of religion. This time her request was granted, and she received a new ID card with her new name.

Unfortunately, this new card also included her old name on the back. And, owing to a legislative amendment that had come into effect while Joy's application for a new ID card was being processed, her new card also included a description of her religion as "Islam." (The intervening piece of legislation required that every national ID card must specify a Muslim's religion as Islam; and, along the way, the National Registration Department [NRD] claimed that, while it recognized Lina Joy's new name, it had no authoritative documentary evidence stating that Joy had renounced Islam..$^{58}$ ) When Joy applied to delete the word "Islam" from her ID card, she was ordered to follow the procedures spelled out in Malaysia's National Registration Regulations 1990 (hereinafter, the "1990 Regulations"), which provided her with a set of forms requiring any Muslim applying for a change of name to specify their religion and, then, to provide "[a]ny further documentary evidence as the registration officer may consider necessary to support the accuracy of any particulars submitted." 59

$5^{8}$ The same piece of legislation specified that, among the "reasons" given by those seeking to change their name, "change of religion" was no longer permitted.

59 National Registration Regulations 1990, clause 4(c)(x). 
When Joy submitted her forms specifying her religion as "Kristian" (along with a copy of her baptismal certificate), the presiding NRD officer made a notation saying that the religion of the applicant should be retained as Islam because, scanning the NRD records, there was no authoritative documentary evidence stating that, before Joy became a Christian, she had officially abandoned Islam. ${ }^{60}$ A mere assertion of religious identity by a private citizen (or a recognized religious authority - in this case, the church that issued Joy's baptismal certificate) was not enough. Instead, the state required a three-way combination of (a) individual self-assertion (i.e., individual profession), (b) an acknowledgement by relevant religious authorities (insofar as each religious community in Malaysia was constitutionally entitled to "manage its own ... affairs" [Article 11(3)(a)]), and above all, (c) some type of formal process officially recognized by the state itself. In Malaysia, following the "implied" jurisdiction spelled out in Soon Singh, it was the formal administrative procedure associated with this last element that required Joy, as one seeking to leave Islam, to approach a state-level shari'ah court.

Joy insisted that, as per the form she was asked to complete, her baptismal certificate was sufficient to support "[t]he accuracy of any particulars submitted," ${ }^{61}$ since the particulars actually submitted concerned her status as a Christian. However, the NRD contended that, insofar as Joy was seeking to delete the word Islam from her ID card (and, thus, to change her status from what was in the NRD records), the only satisfactory evidence was a certificate of apostasy from a relevant shari'ah court. ${ }^{62}$ From Joy's perspective, as a person no longer professing Islam, she was not subject to the jurisdiction of Malaysia's shari'ah courts. However, the NRD argued that it was not her professed status as a "Kristian" but her earlier effort to abandon Islam that was at issue (in deleting the word "Islam"). And, as such, the NRD argued that the procedure for adjudicating this act of renunciation - by implication, because the Administration of Islamic Law (Federal Territories) Act (1993) did not mention Muslim apostasy - involved the shari'ah court.

In effect, the question before the Court was regarded as a routine matter of administrative law, albeit one that underpinned the operationalization of a fundamental constitutional right: did the NRD act "reasonably" (i.e., within a defensible understanding of administrative discretion) when it required Joy to obtain a certificate of apostasy from a shari'ah court before deleting the word Islam from her ID card? The case was explicitly framed as a case of "Wednesbury" (un)reasonableness, asking whether the administrative decision taken by the NRD was wrong, capricious, perverse, or absurd - indeed, in the language of the Court of Appeal of England and

\footnotetext{
60 Lina Joy v. Majlis Agama Islam Wilayah Persekutuan and Others [2005] 6, Malayan Law Journal $193,202$.

61 Lina Joy (n. 4), 629.

62 Ibid., 627 .
} 
Wales in Wednesbury Corp ${ }^{63}$ " [s] o unreasonable that no reasonable authority could have ever come to it." ${ }^{4}$

Malaysia's Federal Court, by a 2:1 majority, concurred with Malaysia's Court of Appeal and concluded that, in an administrative sense, the NRD had acted "reasonably" for at least three reasons. First, the Court argued that the NRD's insistence on authoritative evidence from the shari'ah court confirming that Joy was no longer a Muslim was "reasonable." ${ }^{65}$ In particular, the chief justice argued that a mere statutory declaration issued by a person leaving the religion was not enough. ${ }^{66}$ Because renouncing Islam was thought to implicate the terms of Islamic law, it was perfectly reasonable for the NRD to require confirmation from the relevant Islamic authorities who were thought to possess the expertise required to adjudicate such matters. In fact, the Court added that if the NRD had accepted a person's "selfdeclaration" on its own, the NRD might be at risk of "wrongly" designating someone's affiliation with a particular religious group. ${ }^{67}$

Second, agreeing with Malaysia's Court of Appeal, the Federal Court conceded that the relevant Administration of Islamic Law (Federal Territories) Act (1993) granting jurisdiction to the shari'ah courts in various matters did not provide any guidance regarding the procedures governing Muslim apostasy. Yet, following Soon Singh, the Court declared that the jurisdiction of the shari'ah courts was "implied." per Md Hakim Lee, the Court accepted the conservative view that the judiciary must avoid filling legislative lacunae on its own; the courts were simply obliged to encourage each state-level legislature to satisfy its own legal role in specifying the relevant procedures. ${ }^{69}$ In effect, the Court argued that it was legally "reasonable" to expect each actor within Malaysia's constitutionally defined legal-cum-administrative order to play its required part. The alternative - arrogating legislative powers to the Court on the premise that a radical commitment to institutional centralization was required to ensure a defense of fundamental rights - was rejected. This was because such a move was seen as undermining the underpinnings of Malaysia's constitutional order (including its approach to federalism and a constitutional separation of powers)..$^{\circ}$

Third, it is important to stress that the 1990 Regulations did not offer any clear guidance as to what must be provided to correct erroneous particulars on an ID card. Instead, the Court declared that it was within the administrative discretion of each NRD officer to determine which documentary evidence was required "[t]o support the accuracy of any particulars submitted"71 and that, in cases of Muslim apostasy, it

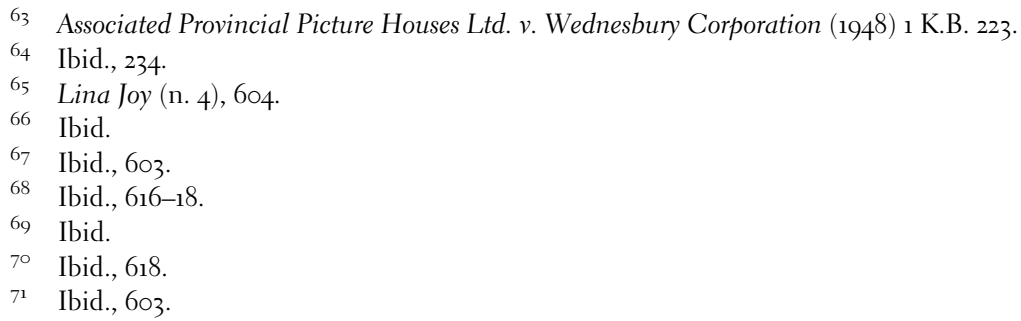


was administratively "reasonable" in light of prevailing jurisprudence to expect some type of certification from Malaysia's state-level shari'ah courts. ${ }^{72}$ The Court stressed that determining the question of whether a person had renounced Islam was not within the jurisdiction of the NRD and that it was not something "[t]he NRD is ... equipped or qualified to decide." 73 In fact the Court in Lina Joy held that, even when a certificate of apostasy was furnished before the NRD, each NRD officer still possessed the discretion to retain or remove the word "Islam" from an ID card. ${ }^{74}$ In Lina Joy, the relationship between fundamental rights and administrative discretion (and judicial deference to such discretion) was made abundantly clear.

For comparative purposes, it is interesting to note that at no point did the Court explicitly state that Lina Joy could not change her religion (in keeping with the fundamental rights outlined in Article 11 of the Malaysian constitution). On the contrary, the Court simply came to the conclusion that Joy's exercise of this freedom in Malaysia was subject to the relevant state regulations. ${ }^{75}$ For the Court, exercising one's rights under Article 11 (as a Muslim) simply required compliance with Malaysia's laws and procedures associated with the renunciation of Islam. ${ }^{76}$ In short, the exercise of Joy's religious freedom could not be recognized by the state unless specific procedures were followed - procedures closely tied to Malaysia's federal constitutional order and the legal authority of its state-level shari'ah courts.

\section{LINA JOY: RIGHTS VS. REASONABLENESS?}

Lina Joy argued that the NRD's actions amounted to a form of trickery preventing the state from officially recognizing her conversion. In her submissions at trial (in the High Court), Joy documented an unfruitful back-and-forth with the NRD. The NRD rejected - without articulating any reason - her first application for a change of name (in which she stated that her reason for this change was her renunciation of Islam). ${ }^{77}$ She put in a second application almost two years later (again citing conversion as the reason for her name change), but this time the NRD did not respond. ${ }^{7}$ She subsequently enquired about the status of her application, whereupon she was told not to disclose her conversion to avoid any difficulties with her application. ${ }^{79}$ In fact it was this advice that led Joy to submit a third application, which was subsequently approved (albeit with a new ID card that specified her religion as "Islam"). ${ }^{80}$ The dissenting judgment prepared by Justice Richard

\footnotetext{
72 Ibid., $6 \circ 4$.

73 Ibid., 602 .

74 Ibid., 6o4.

75 Ibid., 612.

$7^{6}$ Ibid.

77 Ibid., 620.

$7^{8}$ Ibid.

79 Ibid.

8o Ibid., 621.
} 
Malanjum, focusing heavily on the constitutionality of the 1990 Regulations and the matter of official discretion, stressed this protracted series of interactions. ${ }^{81}$ In fact, taking up the question of administrative "reasonableness," Malanjum noted that, within Malaysia's existing policy framework, Joy had been faced with an extremely difficult administrative process followed by an almost impossible additional requirement. ${ }^{82}$ This requirement required Joy to follow a set of procedures concerning the work of a relevant state-level shari'ah court - a statutory set of procedures that, within Malaysia’s Federal Territories, did not (yet) exist.

\section{A. Proceduralizing Apostasy}

Malanjum began his dissenting judgment by accepting that the NRD official who handled Joy's case was entitled to request any documentary evidence "[n]ecessary to support the accuracy of any particulars submitted." ${ }^{83}$ He simply reiterated that the particulars actually submitted concerned Joy's identity as a Christian - hence her baptismal certificate - rather than her status as an ex-Muslim. There was an "abuse of power," he noted, when the NRD "[f]ailed to take into consideration a legally relevant factor, namely ... the documents submitted by the appellant, ... preferring [instead] its policy of requiring a certificate of apostasy from the Federal Territory Syariah Court." ${ }^{4}$ This policy - according to Malanjum - was not a step that had been stipulated in the 1990 Regulations. Indeed, turning specifically to the question of "Wednesbury" (un)reasonableness, he drew attention to the matter of completing a set of forms that did not exist. ${ }^{85}$ For Malanjum, the NRD's insistence on a certificate of apostasy from the Federal Territory shari'ah court was not only illegal but also administratively unreasonable, "[b]ecause under the applicable [state-level] law, the Syariah Court in the Federal Territory has no statutory power to adjudicate on the issue of apostasy." In short, he noted that the NRD "[r]equired the performance of an act that was almost impossible to perform." ${ }^{87}$

81 Ibid., 625-30. Justice Malanjum added: "[T]he conclusion in the majority judgment that the impugned policy adopted by NRD was reasonable within the test of Wednesbury Corporation $v$. Ministry of Housing (1966) 2 Q.B. 275 has unfortunately missed one cardinal principle. The implementation of the policy has a bearing on the appellant's fundamental constitutional right to freedom of religion under Article 11 of the Constitution. Being a constitutional issue it must be given priority independent of any determination of the Wednesbury reasonableness; ... before it can be said that a policy is reasonable within the test of Wednesbury its constitutionality must be first considered." Ibid., 631.

82 Ibid., 632

$8_{3}$ Lina Joy (n. 4), 626 .

84 Ibid., 630 .

85 In Malaysia, different rules for different groups are constitutionally permitted in the context of religious personal law. However, Malanjum focused on a rule pertaining only to "Muslims" (whose ID cards had to "state their religion"); he described this as a case of discrimination beyond the realm of Muslim personal law. See ibid., 639.

86 Ibid., 632.

87 Ibid., 644 . 
This statutory lacuna pertaining to the jurisdiction of the Federal Territory's shari'ah courts thus became the central issue in Lina Joy. Did the NRD exercise its administrative discretion in a "reasonable" manner when it sought to chart a course between (a) the statutory silence of the Federal Territories regarding the work of its shari' ah courts in cases of Muslim apostasy and (b) the guiding jurisprudence of Soon Singh regarding the implied jurisdiction of those very shariah courts? Crucially, Malanjum did not seek to erase the silence of the Federal Territories by legislating from the bench; instead, he adhered to the work of his predecessors in continuing to press for the promulgation of clearly defined laws in each state. In particular, he stressed that, in cases regarding Muslim apostasy (and, thus, fundamental rights), jurisdiction should never be "implied." Following Dalip Kaur (1997), he returned to questions of policymaking and noted that clearly defined procedural guidance should be incorporated "[i]n all state enactments to avoid [any] difficulties of interpretation." 88

\section{B. Regulating Apostasy: State-Level Variation}

Outside of Malaysia's courts, however, this case raised one of the most important questions in Malaysia's constitutional and political order: to what extent should various states, including the Federal Territories, be compelled to confront the issue of Muslim apostasy via explicit state-level enactments and, even beyond this, to what extent should state-level policies reflect a particular "national" standard? Indeed, if such policies were to reflect a national standard, which standard could be said to reflect an (administratively) "reasonable" standard for regulating - and recognizing - Muslim apostasy?

Focusing on the punitive procedures in Pahang (where would-be apostates were seen as committing a crime and punished with the maximum state-level punishment of six lashes, a MYR50oo fine, and three years' imprisonment), some perceived a basic aversion to any legalization of Muslim apostasy. Former Australian High Court Judge Michael Kirby and Malaysian scholars such as Nurjaanah Abdullah, for instance, read Lina Joy's emphasis on the power of state-level shari'ah courts as, prima facie, a denial of fundamental rights. To protect fundamental rights, they noted, such cases regarding apostasy should be removed from the shari' ah courts and returned to the civil courts forthwith. ${ }^{89}$ For Abdullah, the problem lay in the fact that it was virtually impossible to get the required validation from a shari' ah court in most states, as references to such courts were "not merely an administrative or procedural requirement ... [but a] control mechanism over individuals who wish to renounce [Islam]." $9 \circ$ Abdullah added that the very existence of cumbersome shari'ah-court

88 Ibid., 650.

${ }^{89}$ Michael Kirby, "Fundamental Human Rights and Religious Apostasy: The Malaysian Case of Lina Joy," Griffith Law Review 17.1 (2008), 151, 156; Abdullah (n. 1), 281.

$9 \circ$ Abdullah (n. 1), 283 . 
procedures was inappropriate in religious freedom cases, as such procedures patently and often willfully "ignore ... the reality that whether or not a person has renounced Islam is ... a question of fact [and] not of law."

This notion - that state recognition should resemble a frictionless conduit through which religious self-identification could be validated strictly on the basis of an individual's autonomous "choice" of religion - was, however, considered administratively problematic. In fact the judicial majority in Lina Joy directly addressed the problems with this view, arguing that such an approach might have the effect of allowing Muslims to renounce Islam merely to avoid certain constraints associated with Muslim personal law (e.g., constraints on the production of a will excluding certain heirs). Similarly, the trial judge in Lina Joy suggested in the High Court that a complete absence of administrative regulation - that is, an ability to renounce Islam without going through any religious body - would be problematic insofar as Malaysia's constitution explicitly allowed each religious group to "manage its own ... affairs" (Article 11(3)(a)).92

A more nuanced view, however, pressing for a sharply limited set of constraints on Muslim apostasy within Malaysia's shari'ah courts, was articulated by Justice Malanjum, who referred to the (now defunct) procedure previously adopted in the state of Johor according to which the powers of a state-level shari'ah court were limited to "registering" individual declarations of conversion. ${ }^{93}$ In a similar vein, states like Negeri Sembilan recommended a rather limited set of procedures within which, after attending three months of rehabilitative counseling followed by a one-year cooling-off period (to consider repentance), apostates could expect to receive an official certificate of apostasy issued by the shariah court.

These divergent approaches to the proceduralization of Muslim apostasy stretching all the way from "punitive" Pahang (where existing procedures seemed to overlap with outright prohibition) to "permissive" Negeri Sembilan (where this was not the case) - are important. ${ }^{94}$ They are particularly important when it comes to considering what sort of explicit state-level enactments might be introduced in the context of future efforts to move beyond the "implied" jurisdiction in Soon Singh. However, as comparative examples, they still ignore the core political question that

$9^{1} \quad$ Ibid.

92 Lina Joy v. Majlis Agama Islam Wilayah \& Another [2004] 2, Malayan Law Journal 119, 126.

93 "A clear provision," Malanjum noted, could "[i]mpose an obligation on the relevant authority to ... maintain a register of converts who ... executed a deed poll renouncing Islam", Lina Joy, n. 4, 654. In the end, Malanjum stressed the inevitable overlap between fundamental rights and questions about the "reasonableness" of the administrative procedures operationalizing those rights. He argued that the latter should never stifle the former.

94 Two cases are instructive in this respect. Daud bin Mamat and Kamariah bte Ali emerged in Kelantan, which (unlike the Federal Territories that framed Lina Joy) has an enactment specifying the procedures for apostasy. In Daud bin Mamat, the civil court decided that the appellant had to complete a set of required shariah-court procedures that he had not yet done. See Daud bin Mamat \& Others v. Majlis Agama Islam \& Another [2001] 2, Malayan Law Journal 390 and Kamariah bte Ali v. Kerajaan Negeri Kelantan \& Another [2002] 3, Malayan Law Journal 657. 
confronted Lina Joy, namely, why did Malaysia's Federal Territories fail to specify any procedure pertaining to Muslim apostasy at all? As a matter concerning both law and "national" politics, this is the policy-oriented administrative question that framed the experience of Lina Joy.

\section{Politicizing Apostasy: Federal-State Relations}

To explain why the introduction of specific procedures governing Muslim apostasy in Malaysia's Federal Territories was so difficult and, indeed, why the resulting administrative gap (stemming from a persistent statutory lacuna) was seen as "reasonable" by Malaysia's Federal Court, we argue that the problem of religious freedom in Malaysia must be understood in light of (a) historical and political factors pertaining to the country's constitutional architecture and (b) a set of rather delicate (and, to some extent, unresolved) political issues involving the distribution of federal and state-level powers in matters concerning religion.

Malaysia's scheme of federalism is center-heavy. Even a cursory assessment of the legislative distribution of powers in the constitution is enough to highlight this fact: List I of the Ninth Schedule lists twenty-seven matters in which the federal parliament possesses exclusive competence; List II provides only thirteen matters falling exclusively to the states. One of these thirteen matters is Islamic law, but as explained earlier, there is a very limited area of Islamic law within which individual states can legislate. ${ }^{95}$ Despite the common assumption that all matters having to do with Islam are within the exclusive purview of Malaysian states, and despite the fact that statelevel sultans remain the Heads of Islam in their respective states (owing to a carefully engineered compromise during the constitution-making process ${ }^{96}$ ), the power of the federal legislature and, thus, the power of the federal government in matters concerning Islam is, as noted earlier, substantial. ${ }^{97}$ The other point worth reiterating is that the punitive jurisdiction of Malaysia's shariah courts is capped by the Syariah Courts (Criminal Jurisdiction) Act 1965. Limiting the kinds of punishment that state-level shariah courts can impose, this law emerged from the federal legislature..$^{8}$

When it comes to the issue of Muslim apostasy, however, federal-state relations remain extremely complex. List II reserves to state-level legislatures and the federal parliament (in the case of the Federal Territories) the power to define and punish offences by persons professing Islam against the precepts of that religion (including apostasy). Yet, if Malaysia's federal parliament were to exercise this power - creating

95 See Federal Constitution of Malaysia, Section I.A.

$9^{6}$ See generally Fernando (n. 16) and Shah (n. 15), chapter 2.

97 Laws on Islamic banking, finance, and insurance, for instance, would fall within the purview of the federal parliament.

$9^{8}$ See Jaclyn L. Neo and Dian A. H. Shah, "Hudud and the Struggle for Malaysia's Constitutional Soul," Constitutionnet (June 25, 2015), www.constitutionnet.org/news/hudud-and-struggle-malaysias-consti tutional-soul (accessed May 5, 2016). 
a federal law for the Federal Territories that differed from existing state-level laws on this issue (either in a more "punitive" or a more "permissive" direction) - questions would inevitably arise. Article 75 of the constitution clearly states that federal laws will prevail over any (inconsistent) state-level laws. But, with so many different statelevel laws concerning Muslim apostasy, any exercise of the federal legislative power needed to address the procedural lacuna facing Lina Joy could be seen as challenging the legislative remit of the states and, specifically, the power of the sultans to assert their constitutionally defined role as "Heads of Islam" in their respective states. Indeed, federal legislation in this sensitive area might be seen as an effort to pressure Malaysia's state-level sultans to conform to federal standards.

This pressure would not be overlooked by Malaysia's states, particularly since the federal government, through JAKIM, has already stepped up its efforts to standardize "state-level" Islamic laws, including those pertaining to Muslim personal matters like marriage, divorce, and inheritance. It is notable, however, that this push for harmonization has not touched the domain of Muslim apostasy (even though the imposition of capital punishment for unrepentant apostates - a measure that has been proposed, at various times, in states like Kelantan and Terengganu - is blocked by Malaysia's federal Syariah Courts [Criminal Jurisdiction] Act 1965). From an historical perspective, efforts to encourage centralization in matters pertaining to Islam remain highly controversial, particularly in light of long-standing frictions regarding the balance of federal and state-level powers.

Malaysia's sultans explicitly raised strong reservations during Malaysia's pre-independence constitution-making process regarding the inclusion of a constitutional provision cementing Islam as the religion of the Malayan federation, fearing that such a provision would shift the locus of authority in Islamic matters to the central government. Indeed, it is only after these sultans received clear assurances that their regional authority in matters regarding Islam would not be lost that they agreed to the inclusion of this provision. In fact Malaysia's sultans were assured that, even if a federal-level government department were established for religious matters, that department would not exist under the purview of an elected federal government as it does (in the form of JAKIM) today. They were assured that such a department would only serve to "coordinate" the federation and the states under the purview of Malaysia's rotating king (i.e., the Yang di-Pertuan Agong). ${ }^{99}$

Since the earliest days of the constitution-making process, Malaysia's regional sultans have registered persistent concerns about the effect of non-Muslim proselytism on Muslims, suggesting that questions of Muslim apostasy were already a sensitive issue. ${ }^{100}$ This is not surprising insofar as Malaysia's sultans derive both their religious authority and political legitimacy from " $[\mathrm{M}]$ uslim notions of ...

100 Ibid., 112. It was for this reason that the sultans objected to the inclusion the right to propagate one's religion in the constitution. 
rule." ${ }^{\text {101 }}$ Indeed, while the federal legislature may well pass laws to regulate the process of Muslim apostasy in Malaysia's Federal Territories, doing so would almost certainly push the federal government into an enormous political clash. It would, quite simply, stir up a host of questions about the shape of Malaysia's constitutional federalism, with specific reference to religious policymaking and the religious prerogatives of Malaysia's state-level sultans. The statutory gap facing Lina Joy was awkward; but, for historical, constitutional, and political reasons, it is not difficult to understand why the deferential behavior of the NRD, vis-à-vis state-level procedures, was considered administratively "reasonable."

To guarantee harmony between the versions of Islamic law applied in different units of the Malaysian federation, including the Federal Territories, some have suggested that Malaysia should have a Grand Mufti "whose opinions would bind all Muslims." ${ }^{" 102}$ However, Farid Shuaib reports that, so far, this suggestion has received a negative response: "The federal government could not establish such an office," he explains, "unless the states voluntarily agree to subordinate their Muftis to a federal Mufti," and this "the states have resisted."103 Turning specifically to the pattern of statutory inaction that frustrated Lina Joy, Shuaib notes that the creation of a Grand Mufti able to make fatwas for the whole of Malaysia would require a constitutional amendment. But this is unlikely. Malaysia's regional sultans, he explains, "have shown their readiness to be firm in situation[s] related to their position." 104

The constitutional amendment that, according to Shuaib, would be needed before Malaysia's parliament could specify a "national" punishment for the so-called "crime" of Muslim apostasy was not introduced during the fifty years that UMNO and its BN coalition held the requisite two-thirds majority in parliament (19572008). With the demise of that supermajority in 2008, the policymaking context regulating Muslim apostasy and, therein, the operationalization of religious freedom, has shifted. In short, the possibility of introducing such a constitutional amendment and, then, a "national" law governing Muslim apostasy has declined.

\section{CONCLUSION}

The right to freely choose one's religion (i.e., religious self-identification) and the formal procedures underpinning a state's recognition of one's faith are closely linked. They are tied together by administrative procedures, but those procedures

101 See M. B. Hooker, "Muhammadan Law and Islamic Law," in M. B. Hooker (ed.), Islam in SouthEast Asia (Brill, 1997), 171, and Donald L., Horowitz, Ethnic Groups in Conflict (University of California Press, 2000), 226.

102 Shuaib, “The Islamic Legal System in Malaysia” (n. 20), 111.

103 Ibid. As Shuaib points out, "[t]here is a National Fatwa Committee, which was set up in 1970 and is currently placed within the Department of Islam of Malaysia in the Prime Minister's Office. This Committee may deliberate on issues relating to Islam but its recommendation ... is not binding on the states."

104 Shuaib, "Strengthening Administrative Institutions of Islamic Law" (n. 20), 451. 
vary from place to place in ways that directly shape the operationalization of religious freedom as a fundamental constitutional right. In Malaysia, the operationalization of religious freedom is shaped by specific administrative procedures, but historical, constitutional, and political contingencies have shaped the way in which those procedures are designed from state to state within the country, including their absence in Malaysia's Federal Territories and certain other states. These contingencies also explain Malaysia's failure to close the procedural gap that prevented Lina Joy from transforming her religious self-identification into a case of state recognition.

Conventionally, religious freedom is understood as an inherently negative right, meaning that states must not encroach on an individual's freedom to choose or change her religion. However, insofar as this right is guaranteed by national constitutions and international human rights instruments, this particular formulation targeting the forum internum fails to appreciate the relationship between religious self-identification and the administrative procedures underpinning state recognition. The central issue is this: at what point do the bureaucratic procedures underpinning the state's recognition of one's religious self-identification become administratively "unreasonable" in ways that constitute an abuse of one's fundamental rights?

Given the intricacies of Malaysia's legal system, one might appreciate the need to formalize the procedures governing conversion into or out of Islam. For specific historical reasons, the Malaysian constitution carves out a realm of specific (and exclusive) jurisdiction for state-level sharíah courts in matters pertaining to Islam, suggesting that, at the very least, an official record of one's religious identity is necessary to ensure that the application of shari'ah-based laws is strictly limited to those professing the religion of Islam. Yet, building on this limitation, there have been several cases - particularly in divorce and custody battles - where a spouse converts into Islam and then claims that, insofar as he or she is now governed by sharíah, prior obligations under civil law (e.g., obligations related to spousal maintenance) are no longer deemed to apply. ${ }^{105}$ Lina Joy reminds us that, legally speaking, forms of religious identification are closely tied to formal administrative procedures underpinning state recognition.

To obtain state recognition, asking Lina Joy to follow a set of procedures that did not yet exist may seem (normatively) unreasonable - in many ways, an overzealous restriction on Joy's fundamental right to religious freedom. However, the case of Lina Joy reminds us that there is much to be gained (analytically) from a detailed empirical understanding of the relationship between religious self-identification and historically contingent questions of procedure - historically contingent questions of administrative procedure that underpin each state's recognition of religious identity and, therein, its manifestations within the public realm. It is this empirical 
understanding of historically and politically embedded debates about administrative procedure (and administrative "reasonableness") that, we argue, deserves more attention among those with an interest in the operationalization of religious freedom worldwide.

The absence of explicit statutory provisions governing Muslim apostasy in Malaysia's Federal Territories was not enough to persuade Malaysia's Federal Court that the regulatory requirements set by Malaysia's National Registration Department (requiring a certificate of apostasy from the relevant shari'ah court) were "unreasonable." On the contrary, the Court held that it was administratively reasonable for the NRD to require this certificate because apostasy was a matter to be addressed according to (state-level) Islamic principles. Requiring such a certificate, in other words, was (a) within the ambit of the administrative discretion afforded to the National Registration Department and (b) not so illogical (in Malaysia) as to fail a "Wednesbury" reasonableness test.

The question of administrative reasonableness in Lina Joy also implicated a rather sensitive feature of interbranch constitutional politics. Indeed, for specific historical, political, and constitutional reasons, the Federal Court refused to encroach on Malaysia's state-level shari'ah courts in matters pertaining to Islam. Moreover, it was conscious not to disrupt Malaysia's approach to center-state relations in legislative and judicial matters specifically pertaining to shariah. The Court believed that there was a clear constitutional mandate under the Ninth Schedule for Malaysia's state-level shari'ah courts to address these matters, even in the absence of any statutory provisions granting jurisdiction to those courts. Indeed, this exercise of judicial restraint in the face of complex political considerations is not unusual; Malaysia's Federal Court simply concluded that the NRD had acted "reasonably" in the sense of arriving at a course of administrative action that made sense within the context of Malaysian history and politics, the Malaysian constitution, and Malaysian administrative law.

In the end, the Federal Court's approach in Lina Joy had the effect of prohibitingwhether intentionally or not - the formalization of Lina Joy's choice of religion, i.e., her religious self-identification. Even if Joy had approached the shari'ah courts of Malaysia's Federal Territories, however, it is unclear which "procedures" she would have been expected to complete to obtain a certificate of apostasy. Without further legislative action, as demanded by the courts, her fundamental rights could not be operationalized and, as a result, her right to religious freedom was denied. 